\title{
Pr and Ti co-doped Strontium Ferrite as a Novel Hydrogen Electrode for Solid Oxide Electrolysis Cell
}

Lijuan Zhang ${ }^{\text {a }}$, Xingbao Zhu ${ }^{\text {a }}$, Zhiqun Cao ${ }^{a}$, Zhihong Wang ${ }^{\text {a, b }}$, Wenyuan Li $^{c}$, Lin Zhu ${ }^{\text {a }}$, Pengzhang $\mathrm{Li}^{\mathrm{a}}$, Xiqiang Huang ${ }^{\mathrm{a}}$, Zhe Lü ${ }^{\mathrm{a}, *}$

${ }^{a}$ Department of Physics, Harbin Institute of Technology, Harbin 150001, China.

${ }^{\mathrm{b}}$ School of Chemical Engineering and Technology, Harbin Institute of Technology, Harbin 150001, China.

${ }^{\mathrm{c}}$ Mechanical \& Aerospace Engineering Department, Benjamin M. Statler College of Engineering \& Mineral Resources, West Virginia University, Morgantown, WV 26506-6106, USA

\section{ABSTRACT}

Pr and Ti co-doped strontium ferrite oxide $\operatorname{Pr}_{0.3} \mathrm{Sr}_{0.7} \mathrm{Ti}_{0.3} \mathrm{Fe}_{0.7} \mathrm{O}_{3-\delta}$ (PSTF) has been examined as a hydrogen electrode for solid oxide electrolysis cell (SOEC). X-ray diffraction analysis shows that the PSTF material maintains phase stability during 20 hours of treatment under $5 \% \mathrm{H}_{2} / \mathrm{N}_{2}$ conditions. An SOEC with a configuration of PSTF || $\mathrm{SDC}|\mathrm{YSZ}| \mid \mathrm{LSM}$-YSZ operates under various $\mathrm{H}_{2} \mathrm{O}$ concentrations and current densities. As can be observed from the AC impendence spectra of the PSTF electrode, $\mathrm{H}_{2} \mathrm{O} / \mathrm{H}_{2}$ adsorption desorption or surface diffusion process is the main rate-limiting step for steam electrolysis reaction. The low-frequency arc $R_{L}$ obviously depends on the $\mathrm{H}_{2} \mathrm{O}$ concentration and the electrolysis current density. Steam starvation in hydrogen electrode occurs at low $\mathrm{H}_{2} \mathrm{O}$ concentration and large current density. A maximum current density of $302 \mathrm{~mA} \mathrm{~cm}^{-2}$ is obtained at an electrolysis voltage of $1.46 \mathrm{~V}$ in $\mathrm{Ar} / \mathrm{H}_{2} / 60 \% \mathrm{H}_{2} \mathrm{O}$ at $800{ }^{\circ} \mathrm{C}$. The corresponding polarization resistance of PSTF electrode is as small as $0.25 \Omega \mathrm{cm}^{2}$. This study demonstrates that

\footnotetext{
* Corresponding authors: Center for Condensed Matter Science and Technology, Department of Physics, Harbin Institue of Technology, No.92 Xidazhi Street, Harbin, Heilongjiang, P.R.China.

E-mail address: 1vzhe@ hit.edu.cn (Z Lü).
} 
$\mathrm{Pr}_{0.3} \mathrm{Sr}_{0.7} \mathrm{Ti}_{0.3} \mathrm{Fe}_{0.7} \mathrm{O}_{3-\delta}$ is a promising hydrogen electrode material of SOEC for $\mathrm{H}_{2} \mathrm{O}$ electrolysis.

Keywords: Solid oxide electrolysis cell; $\operatorname{Pr}_{0.3} \mathrm{Sr}_{0.7} \mathrm{Ti}_{0.3} \mathrm{Fe}_{0.7} \mathrm{O}_{3-\delta}$; Hydrogen electrode; Steam electrolysis

\section{Introduction}

Solid oxide electrolysis cell (SOEC), which operates reversely as the solid oxide fuel cell (SOFC), has attracted more and more attention because it can directly and efficiently convert renewable electrical energy into chemical fuel energy [1-4]. SOEC is commonly used in hydrogen production from $\mathrm{H}_{2} \mathrm{O}$ electrolysis and $\mathrm{CO}_{2}-\mathrm{H}_{2} \mathrm{O}$ co-electrolysis. For $\mathrm{H}_{2} \mathrm{O}$ electrolysis, when voltage is exerted on the SOEC, water molecules are reduced into hydrogen and oxygen ions at the hydrogen electrode surface. Oxygen ions then pass through the dense electrolyte and are oxidized to oxygen at the oxygen electrode side $[1,5]$. The reaction of SOEC can be written as:

$$
\begin{gathered}
\mathrm{H}_{2} \mathrm{O}+2 \mathrm{e}^{-} \rightarrow \mathrm{H}_{2}+\mathrm{O}^{2-} \\
\mathrm{O}^{2-} \rightarrow \frac{1}{2} \mathrm{O}_{2}+2 \mathrm{e}^{-} \\
\mathrm{H}_{2} \mathrm{O} \rightarrow \mathrm{H}_{2}+\frac{1}{2} \mathrm{O}_{2}
\end{gathered}
$$

Due to the similarity, the anode/cathode of SOFC can be used as cathode/anode for SOEC. The conventional anode of SOFC, Ni-YSZ, has been widely used as the hydrogen electrode of SOEC for high temperature steam electrolysis and exhibits outstanding performance $[6,7]$. However, a high concentration of $\mathrm{H}_{2}$ must be fed to $\mathrm{Ni}$-YSZ hydrogen electrode to protect $\mathrm{Ni}$ against oxidation. In addition, Ni-YSZ electrode shows poor redox stability as the agglomeration of $\mathrm{Ni}$ particles during prolonged operation at elevated temperature [8-10]. Therefore, active and redox-stable 
perovskite oxides have been investigated as the hydrogen electrode materials of SOEC. In recent years, $\mathrm{La}_{1-\mathrm{x}} \mathrm{Sr}_{\mathrm{x}} \mathrm{Fe}_{1-\mathrm{y}} \mathrm{Ti}_{\mathrm{y}} \mathrm{O}_{3-\delta}(0.2<\mathrm{x}<0.8,0.2<\mathrm{y}<0.5)$ were investigated to determine their suitability as oxygen membrane materials [11]. R. Martínez-Coronado et al. [12] demonstrated that oxygen-stoichiometric $\mathrm{La}_{0.5} \mathrm{Sr}_{0.5} \mathrm{Fe}_{0.5} \mathrm{Ti}_{0.5} \mathrm{O}_{3} \quad$ perovskite and oxygen-deficient $\mathrm{La}_{0.5} \mathrm{Sr}_{0.5} \mathrm{Fe}_{0.5} \mathrm{Ti}_{0.5} \mathrm{O}_{2.75}$ composition could be considered as alternative hydrogen electrodes and oxygen electrodes for SOFCs. Cao et al. recently proposes a hydrogen electrode material of $\mathrm{La}_{0.3} \mathrm{Sr}_{0.7} \mathrm{Ti}_{0.3} \mathrm{Fe}_{0.7} \mathrm{O}_{3-\delta}$, which shows a good redox stability and durability in pure $\mathrm{CO}_{2}$ and excellent electrocatalytic activity for $\mathrm{H}_{2}$ electrochemical combustion and $\mathrm{CO}_{2}$ electrolysis $[13,14]$. In fact, $\mathrm{SrFeO}_{3-\delta}$-based perovskites have been studied for more than 10 years. However, pure $\mathrm{SrFeO}_{3-\delta}$ is inadequate as hydrogen electrode material of SOFC or SOEC due to its low redox stability $\left(\mathrm{Fe}^{4+}\right.$ to $\left.\mathrm{Fe}^{3+}\right)[15,16]$. A-site and/or B-site doping is reported to significantly affect the lattice structure and physical properties of $\mathrm{ABO}_{3}$ perovskite oxide. It was reported that the presence of $\mathrm{Ti}^{3+} / \mathrm{Ti}^{4+}$ ions in the $\mathrm{B}$-site stabilized the neighboring oxygen octahedral $\left(\mathrm{BO}_{6}\right)$, leading to enhanced structural stability and tolerance towards chemical reduction of the strontium ferrite oxides [17-19]. However, the conductivity and electrochemical performance of the $\mathrm{SrFe}_{1-\mathrm{x}} \mathrm{Ti}_{\mathrm{x}} \mathrm{O}_{3-\delta}$ decrease and thermal expansion coefficient increases with increasing Ti content [17, 19]. Yaremchenko et al. [20, 21] reported that Pr at the A-site could remarkably affect the oxygen non-stoichiometry and conductivity of doped $\mathrm{Sr}_{1-\mathrm{x}} \mathrm{Pr}_{\mathrm{x}} \mathrm{TiO}_{3 \pm \delta}$. Ren et al. [22] observed that the ionic conductivity of $\operatorname{Pr}_{0.8} \mathrm{Sr}_{0.2} \mathrm{FeO}_{3-\delta}$ was more than one order of magnitude higher than that of $\mathrm{La}_{0.8} \mathrm{Sr}_{0.2} \mathrm{FeO}_{3-\delta}$. And as cathode materials for SOFC, $\operatorname{Pr}_{0.8} \mathrm{Sr}_{0.2} \mathrm{FeO}_{3-\delta}$ as well as $\mathrm{La}_{0.8} \mathrm{Sr}_{0.2} \mathrm{FeO}_{3-\delta}$ exhibits identical impedance.

Inspired by the results above, in this work we co-dope $\mathrm{Pr}$ and $\mathrm{Ti}$ to strontium 
ferrite in order to improve the phase stability and the electrochemical activity. $\operatorname{Pr}_{0.3} \mathrm{Sr}_{0.7} \mathrm{Ti}_{0.3} \mathrm{Fe}_{0.7} \mathrm{O}_{3-\delta}$ as a hydrogen electrode material is examined in various electrolyzing conditions. The performance and stability of this material is characterized, the rate-limiting step is identified and the underlying cause is discussed.

\section{Experimental}

$\mathrm{Pr}_{0.3} \mathrm{Sr}_{0.7} \mathrm{Ti}_{0.3} \mathrm{Fe}_{0.7} \mathrm{O}_{3-\delta}$ (PSTF) powders were synthesized using a solid state reaction method. $\operatorname{Pr}_{6} \mathrm{O}_{11}$ (98.0\%, Shanghai YUELONG New Materials Co. Ltd., China), $\mathrm{SrCO}_{3}$ (99.5\%, Sinopharm Chemical Reagent Co. Ltd., China), $\mathrm{TiO}_{2}(98.0 \%$, Sinopharm Chemical Reagent Co. Ltd., China), and $\mathrm{Fe}_{2} \mathrm{O}_{3}$ (99.0\%, Sinopharm Chemical Reagent Co. Ltd., China) were mixed in stoichiometric ratio and ball-milled for $20 \mathrm{~h}$. Dry mixed powders were uniaxially pressed into pellets and then calcined at $1400{ }^{\circ} \mathrm{C}$ for $5 \mathrm{~h}$ in air. $\mathrm{Sm}_{0.2} \mathrm{Ce}_{0.8} \mathrm{O}_{1.9}$ (SDC) powders were prepared using citric acid assisted method as reported elsewhere and calcined at $800{ }^{\circ} \mathrm{C}$ for $2 \mathrm{~h}$ in air [23]. X-ray diffraction (XRD, PANalytical X'Pert Power, $\mathrm{Cu} \mathrm{K} \mathrm{K}_{\alpha}$ radiation, $\lambda=0.15418 \mathrm{~nm}$ ) was performed to analyze the phase formation of the as-prepared PSTF and evaluate the phase stability of PSTF powders after treated in $50 \mathrm{ml} \mathrm{min}{ }^{-1}$ of $5 \% \mathrm{H}_{2} / \mathrm{N}_{2}$ at $800{ }^{\circ} \mathrm{C}$ for $20 \mathrm{~h}$.

Electrical conductivity of PSTF was measured using KEITHLEY 2400 Source Meter by four-prode DC technique in $5 \% \mathrm{H}_{2} / \mathrm{N}_{2}$ at a flow rate of $50 \mathrm{ml} \cdot \mathrm{min}^{-1}$. Before test, the sample was pre-sintered at $1400{ }^{\circ} \mathrm{C}$ for $5 \mathrm{~h}$ in air to achieve high density.

$8 \% \mathrm{Y}_{2} \mathrm{O}_{3}-\mathrm{ZrO}_{2}$ powders (China Building Materials Academy, China) were pressed into pellets and sintered at $1400{ }^{\circ} \mathrm{C}$ for $6 \mathrm{~h}$ in air. The thickness of YSZ electrolyte was $\sim 400 \mu \mathrm{m}$. SDC slurry (SDC dispersed in mixed appropriate ratio of ethyl cellulose and terpilenol) was spun onto one side of the YSZ electrolyte and then 
sintered at $1300{ }^{\circ} \mathrm{C}$ for $4 \mathrm{~h}$ in air to form a barrier layer in order to prevent reaction between YSZ and PSTF materials. PSTF cathode slurry and 60wt.\% LSM-YSZ anode slurry $\left(\left(\mathrm{La}_{0.75} \mathrm{Sr}_{0.25}\right)_{0.95} \mathrm{MnO}_{3-\delta}\right.$, Ningbo SOFCMAN Energy Technology Co., Ltd) were prepared as well as SDC slurry and symmetrically printed onto the SDC side and YSZ side respectively (in the area of $\sim 0.12 \mathrm{~cm}^{2}$ ) and then sintered at $1200{ }^{\circ} \mathrm{C}$ for $2 \mathrm{~h}$ in air to form YSZ electrolyte supported PSTF||SDC|YSZ||LSM-YSZ single cell. Ag paste was used as current collectors and dried at $450{ }^{\circ} \mathrm{C}$ for 30 min after painting onto both electrode surfaces. Ag reference electrode was deposited on YSZ pellet to the LSM-YSZ side with the area $<0.02 \mathrm{~cm}^{2}$. It is over $2 \mathrm{~mm}$ away (about 5 times to the thickness of YSZ electrolyte) from LSM-YSZ electrode edge. Fig. 1 showed configuration of the single cell. Ag wire was used as lead wire.

Electrochemical performance tests were performed at $800{ }^{\circ} \mathrm{C}$ in $\mathrm{Ar} / \mathrm{H}_{2} /(20 \%, 40 \%$ and $60 \%) \mathrm{H}_{2} \mathrm{O}$, with $\mathrm{Ar}$ and $\mathrm{H}_{2}$ at a volume ratio of $4: 1$ and a total flow rate of $50 \mathrm{ml}$ $\min ^{-1}$. Current density versus voltage curves ( $j-V$ curves), AC impedance spectra and cell operation durability were tested by an electrochemical workstation (Biologic VSP, France). The frequency of AC impedance spectra ranged from $100 \mathrm{kHz}$ to $0.1 \mathrm{~Hz}$ and the AC amplitude was $10 \mathrm{mV}$. The cross-sections microstructure of the cell was analyzed using a scanning electron microscope (SEM, Hitachi, SU8000, Japan).

\section{Result and Discussion}

\subsection{Material characterization and microstructures of the electrolyzer}

XRD pattern of PSTF powders in Fig. 2 confirms a single phase of cubic perovskite structure (JCPDS: \#34-0638, $a=3.8831 \pm 0.0030 \AA, V=58.5503 \pm 0.1347 \AA^{3}$ ). As shown in the inset of Fig. 2, no secondary phase can be found after reducing PSTF powder in $5 \% \mathrm{H}_{2} / \mathrm{N}_{2}$ at $800{ }^{\circ} \mathrm{C}$ for $20 \mathrm{~h}$, demonstrating the high redox stability of PSTF. At the same time, it can be seen that the peaks of PSTF after reduction slightly 
shift to small angle, which can be explained as cell expansion $(a=3.9021 \pm 0.0016 \AA$, $\left.V=59.4172 \pm 0.0748 \AA^{3}\right)$ resulted from the transition of $\mathrm{Fe}^{4+}(0.585 \AA)$ to $\mathrm{Fe}^{3+}(0.645 \AA)$ and/or $\mathrm{Ti}^{4+}(0.605 \AA)$ to $\mathrm{Ti}^{3+}(0.670 \AA)[24,25]$. As reported in the literature [26], a phase transformation from $\mathrm{SrFeO}_{3-\delta}$ to $\mathrm{Sr}_{2} \mathrm{Fe}_{2} \mathrm{O}_{5}$ occurred after annealing in a flow of $5 \% \mathrm{H}_{2} / \mathrm{Ar}$ at $800{ }^{\circ} \mathrm{C}$ for $24 \mathrm{~h}$. In comparison, PSTF shows much better at phase stability in reducing atmosphere.

The mixed conductivity of PSTF is $0.25 \mathrm{~S} \mathrm{~cm}^{-1}$ at $800{ }^{\circ} \mathrm{C}$ in $5 \% \mathrm{H}_{2} / \mathrm{N}_{2}$. It is significantly higher than that of pure $\mathrm{SrFeO}_{3}$ in $5 \% \mathrm{H}_{2} / \mathrm{Ar}$ at $800{ }^{\circ} \mathrm{C}$, e.g. $0.03 \mathrm{~S} \mathrm{~cm}^{-1}$ [27], which confirms that doping $\mathrm{Pr}$ enhances the conductivity of $\mathrm{SrFeO}_{3}$-based oxide. The conductivities of common hydrogen electrode materials are listed in Table 1. PSTF possesses an acceptable electrical conductivity, and is comparable to the other hydrogen electrode materials.

Fig. 3 presents the microstructures of PSTF||SDC|YSZ |LSM-YSZ cell. The thickness of these four components is about $30,10,400$ and $30 \mu \mathrm{m}$, respectively. The adhesion between each other is good. The thickness and density of SDC barrier layer can effectively separate the YSZ from PSTF materials. The submicron granularity and particles distribution both PSTF and LSM-YSZ electrode is quite uniform.

\subsection{In-situ AC impendence spectra of the PSTF electrode}

In-situ AC impendence spectra can be utilized to investigate the change of cell/electrode resistance under different atmosphere or current density conditions. In order to evaluate the impendence of PSTF electrode in the electrolysis process, the three-electrode method is used with PSTF electrode as working electrode and Ag electrode as reference electrode. The AC impedance data of the PSTF electrode in $\mathrm{Ar} / \mathrm{H}_{2} / 20 \% \mathrm{H}_{2} \mathrm{O}, \mathrm{Ar} / \mathrm{H}_{2} / 40 \% \mathrm{H}_{2} \mathrm{O}$, and $\mathrm{Ar} / \mathrm{H}_{2} / 60 \% \mathrm{H}_{2} \mathrm{O}$ under a series of applied current density from 0 to $-300 \mathrm{~mA} \mathrm{~cm}{ }^{-2}$ are presented in Fig. 4. Ohm resistance is subtracted 
in order to analyze the polarization resistance clearly. The intercept at low-frequency on the real axis corresponds to the electrode polarization resistance $\left(R_{p}\right)$. There are two arcs in the impedance spectroscopy. Generally, the contributions in $R_{p}$ can be distinguished using the equivalent circuit in Fig. 5: the high-frequency arc $\left(R_{H}\right)$ mainly reflecting the charge transfer process at the electrode/electrolyze interface, and the low-frequency arc $\left(R_{L}\right)$ relating to the steam adsorption, $\mathrm{H}_{2}$ desorption or surface diffusion processes at the PSTF electrode inner surface[30]. It can be observed in Fig. 4 that the $R_{H}$ increase slightly with the increase of steam concentration, which suggests that the concentration of steam has an insignificant influence on the charge transfer process. On the other hand, $R_{L}$ is considerably increased with the increase of the $\mathrm{H}_{2} \mathrm{O}$ content under the open circuit voltage (OCV) condition. Two causes could be involved in this phenomenon. The first is that there is a competition between the adsorption of $\mathrm{H}_{2}$ and steam on the reactive surfaces adjacent to the three phase boundary (TPB) or in porous PSTF electrode bulk. The second is the higher gas diffusion resistance of steam compared to $\mathrm{H}_{2}$ in the porous electrode due to its heavier molecules [31]. With increased electrolysis current density $|j|, R_{L}$ in $\mathrm{Ar} / \mathrm{H}_{2} / 20 \% \mathrm{H}_{2} \mathrm{O}$ gradually exceeds the one in $\mathrm{Ar} / \mathrm{H}_{2} / 40 \% \mathrm{H}_{2} \mathrm{O}$ when $j$ is $-50 \mathrm{~mA} \mathrm{~cm}{ }^{-2}$ and the one in $\mathrm{Ar} / \mathrm{H}_{2} / 60 \% \mathrm{H}_{2} \mathrm{O}$ when $j$ is $-150 \mathrm{~mA} \mathrm{~cm}^{-2}$, which is related to steam starvation in PSTF electrode due to the species transport limitation in porous hydrogen electrode. This phenomenon is mitigated in $\mathrm{Ar} / \mathrm{H}_{2} / 40 \% \mathrm{H}_{2} \mathrm{O}$ and further thoroughly eliminating in $\mathrm{Ar} / \mathrm{H}_{2} / 60 \% \mathrm{H}_{2} \mathrm{O}$.

The relationship between $R_{H}, R_{L}$ and/or $R_{p}$ and current density in the same feeding gas is illustrated in Fig. 6. The $R_{H}$ decreasing with increasing $|j|$ owes to the enhanced charge transfer ability under larger electrolysis current. $R_{L}$ decreases firstly and then increases with improved $|j|$ value for the PSTF electrode in $\mathrm{Ar} / \mathrm{H}_{2} / 20 \% \mathrm{H}_{2} \mathrm{O}$ 
and $\mathrm{Ar} / \mathrm{H}_{2} / 40 \% \mathrm{H}_{2} \mathrm{O}$ in Fig. 6 (a) and (b), but it always keeps decreasing for the PSTF electrode in $\mathrm{Ar} / \mathrm{H}_{2} / 60 \% \mathrm{H}_{2} \mathrm{O}$ in Fig. 6 (c). The diminution of $R_{L}$ is caused by the enhanced electro-catalytic activity under larger electrolysis current, while the raising of $R_{L}$ attributes to steam starvation in porous electrode for lower $\mathrm{H}_{2} \mathrm{O}$ concentration as stated earlier. The obtained result, moreover, shows that the $R_{L}$ is larger than $R_{H}$ and mass transport process is rate-determine-step (RDS) of the PSTF hydrogen electrode reaction. The overall $R_{p}$ is as small as $0.42,0.46$, and $0.60 \Omega \mathrm{cm}^{2}$ in $\mathrm{Ar} / \mathrm{H}_{2} /(20 \%, 40 \%$ and $60 \%) \mathrm{H}_{2} \mathrm{O}$ respectively under $\mathrm{OCV}$ at $800{ }^{\circ} \mathrm{C}$.

\subsection{Electrochemical performance of the electrolyzer}

In order to study the effect of external voltage and steam concentration on electrochemical performance of the PSTF||SDC|YSZ||LSM-YSZ cell, current density with applied voltage curves ( $j$ - $V$ curves) was performed. Fig. 7 shows $j$ - $V$ curves at $800{ }^{\circ} \mathrm{C}$, the OCV is $0.94,0.90$ and $0.87 \mathrm{~V}$ for hydrogen electrode in $\mathrm{Ar} / \mathrm{H}_{2} /(20 \%, 40 \%$ and $60 \%) \mathrm{H}_{2} \mathrm{O}$ respectively, consistent with the Nernst equation, which decreases with the increase of the steam to hydrogen ratio. Positive current densities indicate power generation (SOFC mode) while negative current densities indicate power consumption (SOEC mode) [32]. From Fig. 7, in the SOFC mode, it can be seen that the biggest power density is $98.5,76.7$ and $64.2 \mathrm{~mW} \mathrm{~cm}^{-2}$ for PSTF electrode in $\mathrm{H}_{2} \mathrm{O}$ partial pressure from $20 \%$ to $60 \%$. In the SOEC mode, the relationship between the applied voltage and current density is close to but not strictly linear. Moreover, the electrolysis voltage drops with increasing vapor concentration, indicating the promotion of $\mathrm{H}_{2} \mathrm{O}$ electrolysis that is resulting from the increase of reactants concentration. The maximal current density is $-285.0,-298.2$ and $-302.2 \mathrm{~mA} \mathrm{~cm}^{-2}$ in $\mathrm{Ar} / \mathrm{H}_{2} /(20 \%, 40 \%$ and $60 \%) \mathrm{H}_{2} \mathrm{O}$ at $1.50,1.50$ and $1.46 \mathrm{~V}$, respectively. Comparison of cell performance with other common hydrogen electrode is listed in Table 2. The 
electrolyzer with PSTF electrode exhibits a promising electrochemical performance.

The AC impendence spectra is also used to evaluate the electrochemical performance of the PSTF||SDC|YSZ||LSM-YSZ cell. Fig. 8, Fig. 9 and Fig. 10 shows separately the impendence spectra of the whole electrolyzer in a series of current density for the different feeding gases to the PSTF electrode. Increasing $|j|$ makes $R_{\text {ohm }}$ obviously drop, which is attributed to the elevated cell temperature by the Joule heat for the larger current flowing through the YSZ electrolyte. The intercept at low-frequency corresponds to the total resistance $\left(R_{t}\right)$. It is also noted that $R_{t}$ changes under different current density that means the $j$ - $V$ curves in Fig. 7 are not strictly linear. Different from impendence spectra of the PSTF electrode, there are three contributions in $R_{p}$ can be seen and be fitted using the equivalent circuit in Fig. 11: a high-frequency $\operatorname{arc}\left(R_{H}\right)$ for frequencies between $2.8 \mathrm{kHz}$ and $100 \mathrm{~Hz}$, a medium-frequency arc $\left(R_{M}\right)$ for frequencies between $100 \mathrm{~Hz}$ and $1 \mathrm{~Hz}$, and a low-frequency $\operatorname{arc}\left(R_{L}\right)$ for frequencies between $1 \mathrm{~Hz}$ and $0.1 \mathrm{~Hz}$. Complex gas conversion and redox reaction occurs on both the hydrogen electrode and the oxygen electrode. Therefore, it is not possible to separate completely reaction process from hydrogen electrode to oxygen electrode. However, combined result of $R_{H}$ and $R_{M}$ mainly corresponds to the charge transfer and redox reaction process on two electrodes, which decreases with improved $|j|$ in the same $\mathrm{H}_{2} \mathrm{O}$ concentration respectively. Consistent with the PSTF electrode, this phenomenon suggests the enhanced electro-catalytic activity under larger electrolysis current. Moreover, $R_{L}$ mainly corresponds to the gas dissociative, adsorption and diffusion process of $\mathrm{H}_{2} / \mathrm{H}_{2} \mathrm{O}$ in PSTF electrode and $\mathrm{O}_{2}$ in LSM-YSZ electrode[37, 38]. And it grows with increasing $|j|$ in the same $\mathrm{H}_{2} \mathrm{O}$ concentration. In $\mathrm{Ar} / \mathrm{H}_{2} / 20 \% \mathrm{H}_{2} \mathrm{O}$, the value of $R_{L}$ increases sharply when $|j|$ is larger than $200 \mathrm{~mA} \mathrm{~cm}^{-2}$ which is from mass transport 
limitation. While mass transport limitation improves when higher $\mathrm{H}_{2} \mathrm{O}$ content fed to the PSTF electrode so that growth rate of the $R_{L}$ reduces with the steam concentration from $20 \%$ to $60 \%$. Compared to the literature values as listed in Table 2 , the cell with PSTF electrode shows a competitive polarization resistance.

In order to evaluate the durability of the SOEC with PSTF as hydrogen electrode, the relationship of terminal voltage and run time under the constant electrolysis current density of $-200 \mathrm{~mA} \mathrm{~cm}{ }^{-2}$ is tested with $\mathrm{Ar} / \mathrm{H}_{2} / 60 \% \mathrm{H}_{2} \mathrm{O}$ at $800{ }^{\circ} \mathrm{C}$. As shown in Fig.12, the cell voltage is about $1.3 \mathrm{~V}$ and rises as small as $\sim 2.0 \%$ during $20 \mathrm{~h}$ running. The delamination between LSM-YSZ oxygen electrode and YSZ electrolyte maybe the main reason for rising of the electrolysis voltage after long time operation $[39,40]$. Compare to the LSCM-YSZ hydrogen electrode, the voltage increased by $8.2 \%$ of the cell operated at a constant electrolysis current density of $-0.33 \mathrm{~A} \mathrm{~cm}^{-2}$ with 45 vol.\% $\mathrm{AH}$ and $30 \mathrm{ml} \mathrm{min}{ }^{-1} \mathrm{H}_{2}$ as carrier gas at $850{ }^{\circ} \mathrm{C}$ [31], the cell with PSTF electrode possess basically electrochemical stability in the electrolysis operations.

\section{Conclusion}

A-site and B-site co-doped strontium ferrite perovskite oxide $\operatorname{Pr}_{0.3} \mathrm{Sr}_{0.7} \mathrm{Ti}_{0.3} \mathrm{Fe}_{0.7} \mathrm{O}_{3-\delta}$ has been successfully prepared by solid state reaction method, and are successfully used as cathode of electrolyte support PSTF $\|$ SDC|YSZ $\|$ LSM-YSZ electrolyzer. Its conductivity is $0.25 \mathrm{~S} \mathrm{~cm}^{-1}$ at $800{ }^{\circ} \mathrm{C}$ in $5 \% \mathrm{H}_{2} / \mathrm{N}_{2}$, which is 8 times greater than pure $\mathrm{SrFeO}_{3}$. Favorable performance is obtained at the single cell for $\mathrm{H}_{2} \mathrm{O}$ electrolysis at $800{ }^{\circ} \mathrm{C}$. The current density is $-302.2 \mathrm{~mA} \mathrm{~cm}^{-2}$ and the polarization resistance of the electrolyzer is $0.7 \Omega \mathrm{cm}^{2}$ at an applied voltage of $1.46 \mathrm{~V}$ in $\mathrm{Ar} / \mathrm{H}_{2} / 60 \% \mathrm{H}_{2} \mathrm{O}$. The corresponding polarization resistance of PSTF electrode is as small as $0.25 \Omega \mathrm{cm}^{2}$, which accounts for $36 \%$ of 
total polarization resistance. PSTF exhibits both higher chemical stability after dealing in $5 \% \mathrm{H}_{2} / \mathrm{N}_{2}$ at $800{ }^{\circ} \mathrm{C}$ for $20 \mathrm{~h}$ from XRD analysis, and basically electrochemical stability under reducing gas and larger current density during $20 \mathrm{~h}$ running. In conclusion, perovskite oxide $\operatorname{Pr}_{0.3} \mathrm{Sr}_{0.7} \mathrm{Ti}_{0.3} \mathrm{Fe}_{0.7} \mathrm{O}_{3-\delta}$ is a promising hydrogen electrode material for $\mathrm{H}_{2} \mathrm{O}$ electrolysis in SOEC. At the same time, by optimizing the structure of the electrolyzer and introducing catalysts into the PSTF electrode, the electrochemical performance will be further improved.

\section{Acknowledgments}

The authors gratefully acknowledge the financial support of the National Science Foundation of China (No. 51372057, 21373071).

\section{References}

[1] M. Ni, M.K.H. Leung, D.Y.C. Leung, Int. J. Hydrogen Energy 33 (2008) 2337-2354.

[2] A. Nechache, M. Cassir, A. Ringuedé, J.Power Sources 258 (2014) 164-181.

[3] J. Schefold, A. Brisse, H. Poepke, Electrochim. Acta 179 (2015) 161-168.

[4] Y. Tao, H. Nishino, S. Ashidate, H. Kokubo, M.Watanabe, H. Uchida, Electrochim. Acta 54 (2009) 3309-3315.

[5] W. Jiang, Z. Lü, B. Wei, Z. H. Wang, X. B. Zhu, Y. T. Tian, X. Q. Huang, W. H. Su, Fuel cells $14(2014) 76-82$.

[6] S.W. Tao, J.T.S. Irvine, J. Electrochem. Soc. 151 (2004) A252-A259.

[7] S.D. Ebbesen, M. Mogensen, J.Power Sources 193 (2009) 349-358.

[8] K. Haberko, M. Jasinski, P. Pasierb, M. Radecka, M. Rekas, J.Power Sources 195 (2010) $5527-5533$

[9] J.H. Kim, D. Miller, H. Schlegl, D. McGrouther, J.T.S. Irvine, Chem. Mater. 23 (2011) $3841-3847$.

[10] C. Chatzichristodoulou, M. Chen, P.V. Hendriksen, T. Jacobsen, M.B. Mogensen, Electrochim. Acta 189 (2016) 265-282.

[11] I. Kaus, K. Wiik, K. Kleveland, B. Krogh, S. Aasland, Solid State Ionics 178 (2007) 817-826. 
[12] R. Martínez-Coronado, J. A. Alonso, A. Aguadero, D. Perez-Coll, M. T. Fernández-Díaz, J. Appl. Phys. 2013, 113, 123708-1-123708-7.

[13] Z.Q. Cao, Y.H. Zhang, J.P. Miao, Z.H. Wang, Z. Lü, Y. Sui, X.Q. Huang, W. Jiang, Int. J. Hydrogen Energy 40 (2015) 16572-16577.

[14] Z.Q. Cao, B.Wei, J.P. Miao, Z.H. Wang, Z. Lü, W.Y. Li, Y.H. Zhang, X.Q. Huang, X.B. Zhu, Q. Feng, Y. Sui, Electrochem. Commun. 69 (2016) 80-83.

[15] V.V. Vashuk, L.V. Kokhanovskii, I.I. Yushkevich, Inorg. Mater. 36(1) (2000) 90-96.

[16] M.V. Patrakeev, I.A. Leonidov, V.L. Kozhevnikov, V.V. Kharton, Solid State Sci. 6 (2004) 907-913.

[17] X.L. Yu, W. Long, F.J. Jin, T.M. He, Electrochim. Acta 123 (2014) 426-434.

[18] H. Lu, J.P. Kim, S.H. Son, J.H. Park, Mater. Sci. Eng., B 163 (2009) 151-156.

[19] V.V. Kharton, A.P. Viskup, A.V. Kovalevsky, J.R. Jurado, E.N. Naumovich, A.A.Vecher, J.R. Frade, Solid State Ionics 133 (2000) 57-65.

[20] A.A. Yaremchenko, S.G. Patrício, J.R. Frade, J.Power Sources 245 (2014) 557-569.

[21] X.F. Wang, C. Zhang, G.Z. Zang, S.J. Lv, L.B. Li, J. Alloys Compd. 637 (2015) 277-280.

[22] Y.Y. Ren, R. Küngas, R.J. Gorte, C.S. Deng, Solid State Ionics 212 (2012) 47-54.

[23] B. Wei, Z. Lv, T. S. Wei, D. C. Jia, X. Q. Huang, Y. H. Zhang, J. P. Miao, W. H. Su, Int. J. Hydrogen Energy 36 (2011) 6151-6259.

[24] J. Zhang, K. Xie, Y. Gan, G.J. Wu, B. Ding, Y. Zhang, Y.C. Wu, New J.Chem., 38 (2014) $3434-3442$.

[25] W.T. Qi, C. Ruan, G.J. Wu, Y. Zhang, Y. Wang, K. Xie, Y.C. Wu, Int. J. Hydrogen Energy 39 (2014) 5485-5496.

[26] L. dos Santos-Gómez, J.M. Compana, S. Bruque, E.R. Losilla, D. Marrero-López, J.Power Sources 279 (2015) 419-427.

[27] A.J. Fernández-Ropero, J.M. Porras-Vázquez, A. Cabeza, P.R. Slater, D. Marrero-López, E.R. Losilla, J.Power Sources 249 (2014) 405-413.

[28] J.M. Lee, J.W. Yun, Ceram. Int. 42 (2016) 8698-8705.

[29] S.G. Chen, K. Xie, D.H. Dong, H.X. Li, Q.Q. Qin, Y. Zhang, Y.C. Wu, J.Power Sources 274 (2015) 718-729. 
[30] S.S. Xu, S.G. Chen, M. Li, K. Xie, Y. Wang, Y.C. Wu, J.Power Sources 239 (2013) 332-340.

[31] R.M. Xing, Y.R. Wang, S.H. Liu, C. Jin, J.Power Sources 208 (2012) 276-281.

[32] C.H. Yang, Z.B. Yang, C. Jin, M.L. Liu, F.L. Chen, Int. J. Hydrogen Energy 38 (2013) $11202-11208$.

[33] C. Jin, C.H. Yang, F. Zhao, D. Cui, F.L. Chen, Int. J. Hydrogen Energy 36 (2011) 3340-3346.

[34] Z.B. Yang, N. Xu, M.F. Han, F.L. Chen, Int. J. Hydrogen Energy 39 (2014) 7402-7406.

[35] P. Zhang, G.Q. Guan, D.S. Khaerudini, X.G. Hao, C.F. Xue, M.F. Han, Y. Kasai, A. Abudula, J.Power Sources 276 (2015) 347-356.

[36] G. Tsekouras, J.T.S. Irvine, J. Mater. Chem. 21 (2011) 9367-9376.

[37] B. Ge, J.T. Ma, D.S. Ai, C.S. Deng, X.P. Lin, J.M. Xu, Electrochim. Acta 151 (2015) $437-446$

[38] Y.C. Zhou, X. Meng, X.J. Liu, X. Pan, J.L. Li, X.F. Ye, H.W. Nie, C.R. Xia, S.R. Wang, Z.L. Zhan, J.Power Sources 267 (2014) 148-154.

[39] K.F. Chen, S.P. Jiang, Int. J. Hydrogen Energy 36 (2011) 10541-10549.

[40] K.F. Chen, N. Ai, S.P. Jiang, Int. J. Hydrogen Energy 37 (2012) 10517-10525. 


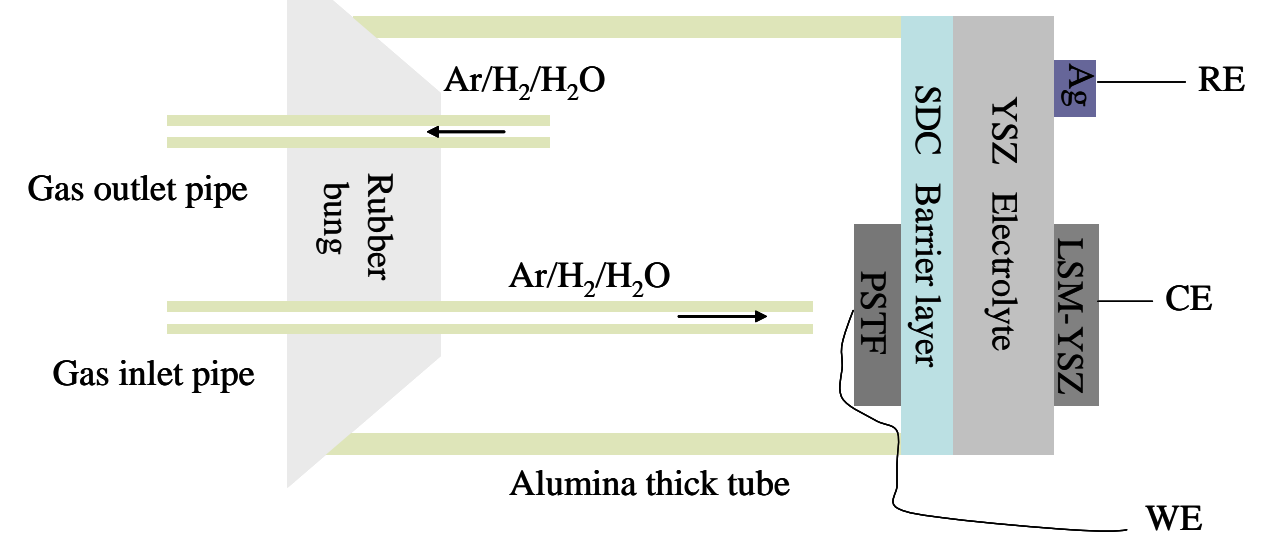

Fig. 1. The structure diagram of the PSTF||SDC|YSZ||LSM-YSZ single cell. 


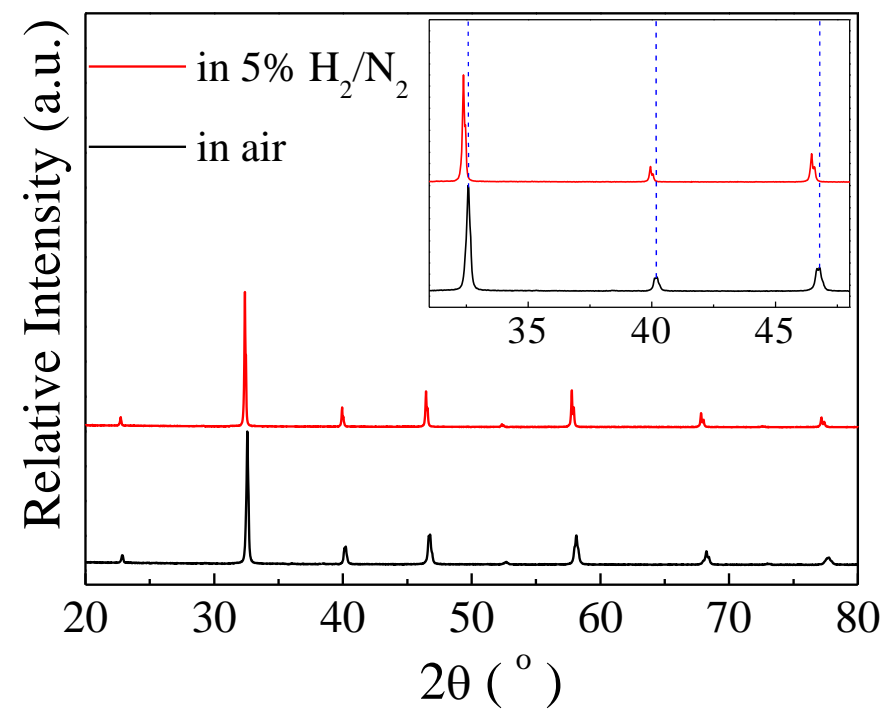

Fig. 2. XRD patterns of the prepared PSTF and after exposed to $5 \% \mathrm{H}_{2} / \mathrm{N}_{2}$ at $800{ }^{\circ} \mathrm{C}$ for $20 \mathrm{~h}$. 

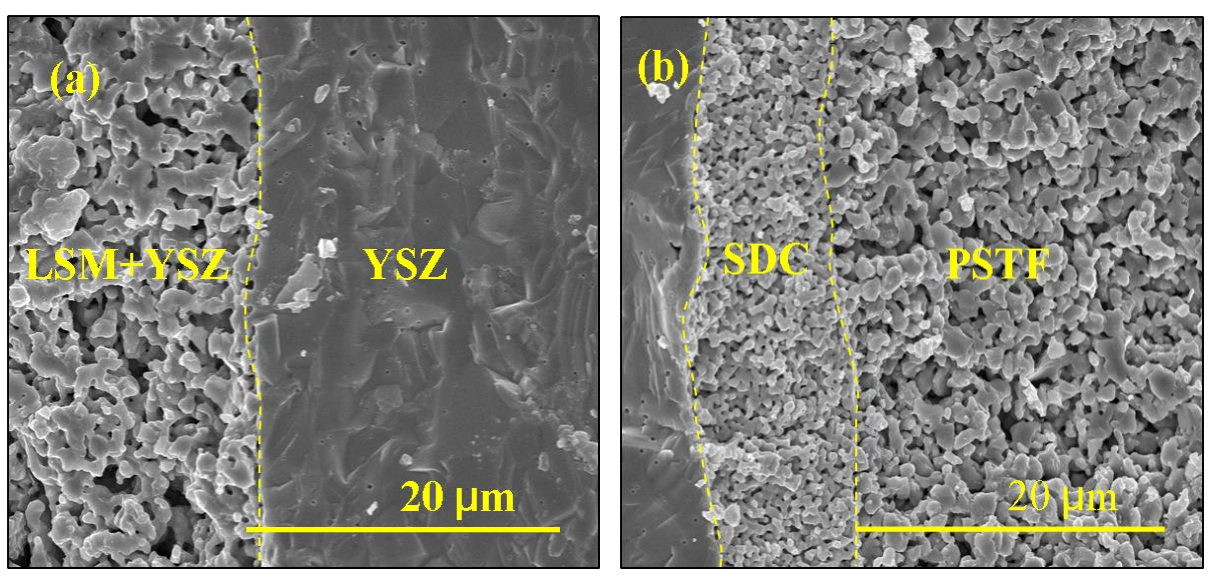

Fig. 3. SEM images of the PSTF||SDC|YSZ||LSM-YSZ electrolysis cell with the PSTF cathode (a) and LSM anode (b). 

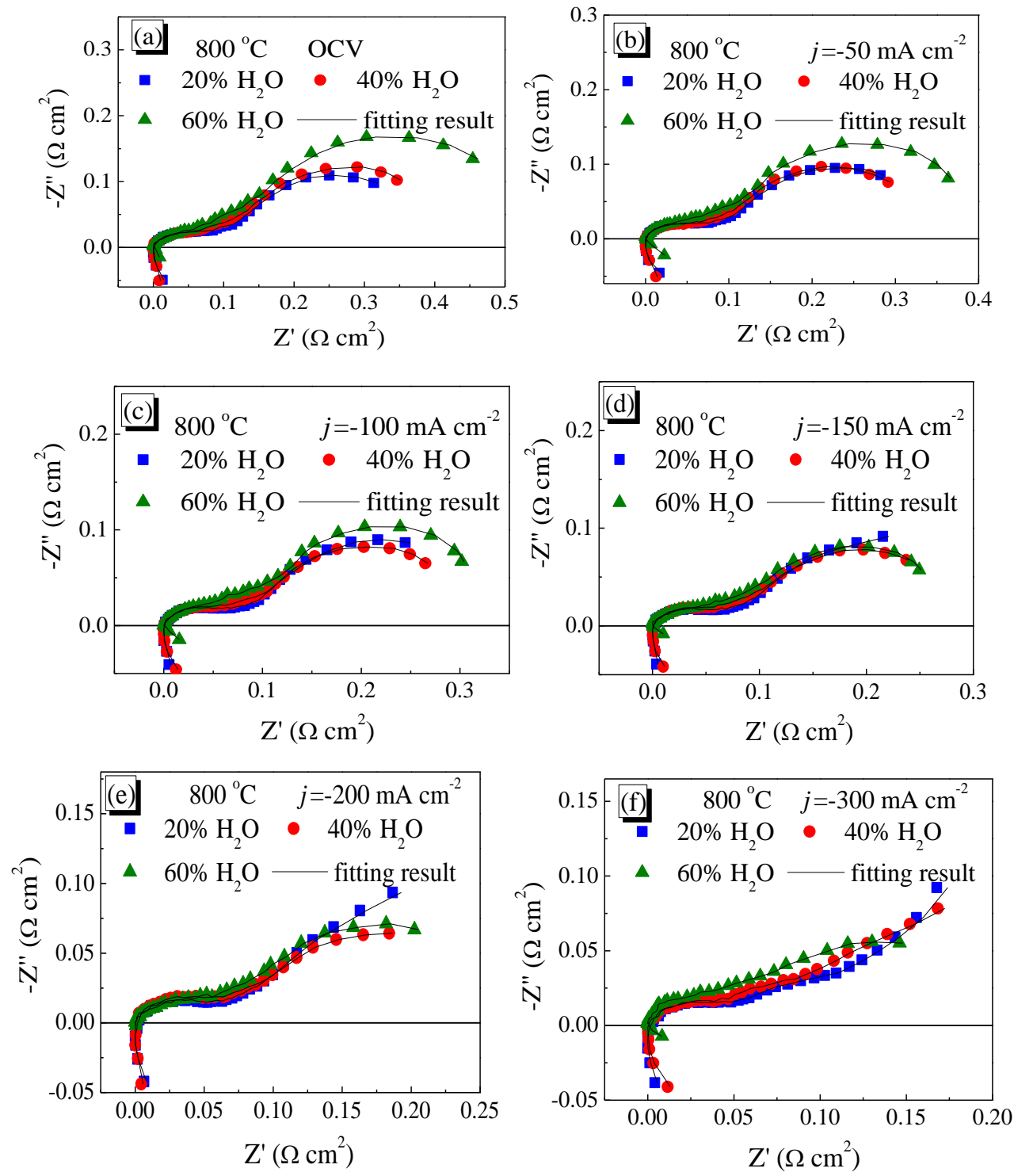

Fig. 4. AC impedance spectra of the PSTF electrode in different $\mathrm{H}_{2} \mathrm{O}$ concentration under a series of current density at $800{ }^{\circ} \mathrm{C}$. 


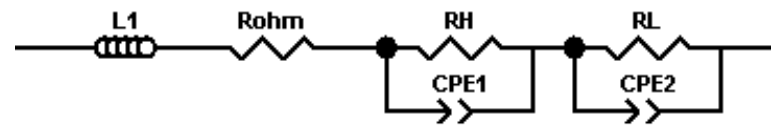

Fig. 5. The equivalent circuit for AC impedance spectra fitting of PSTF electrode at $800{ }^{\circ} \mathrm{C}$. 

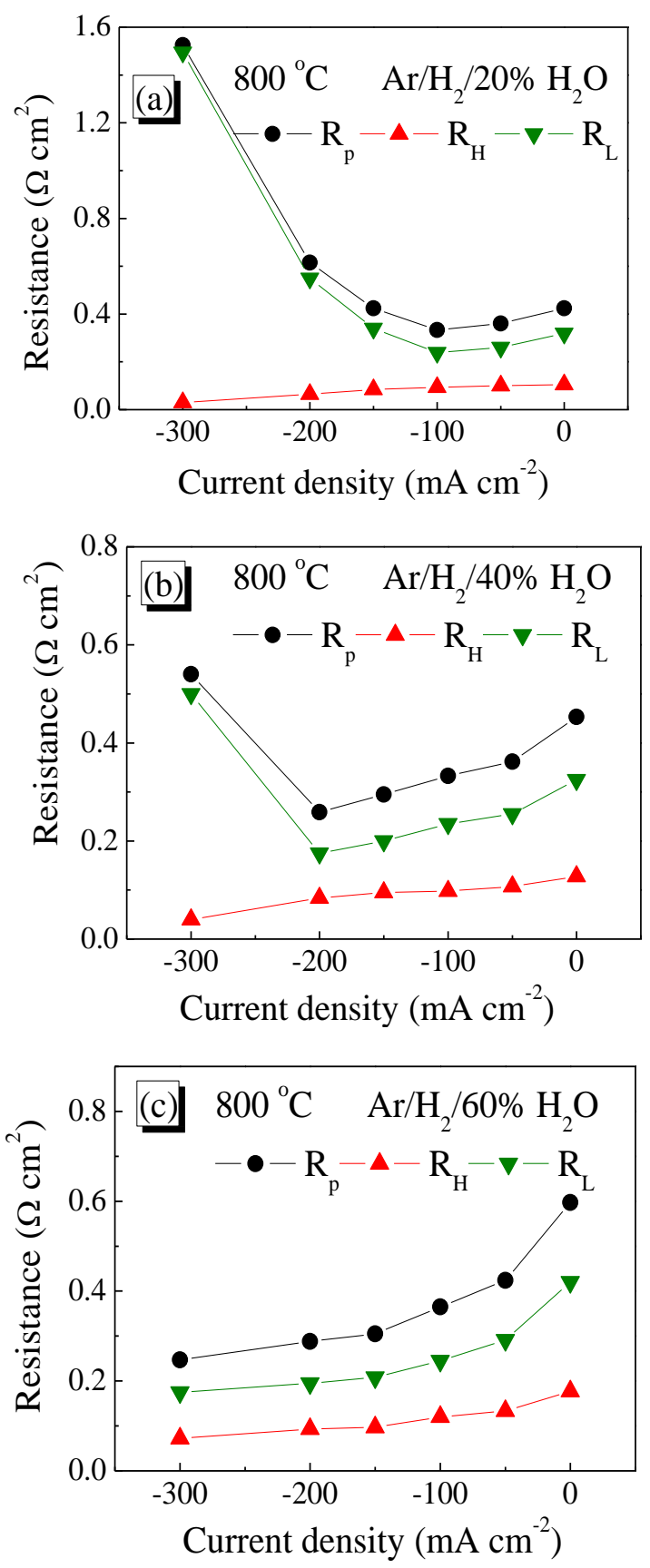

Fig. 6 . The change trend of the fitting $R_{H}, R_{L}$, and $R_{p}$ with electrolysis current density in $\mathrm{Ar} / \mathrm{H}_{2} /(20 \%, 40 \%, 60 \%) \mathrm{H}_{2} \mathrm{O}$ at $800{ }^{\circ} \mathrm{C}$. 


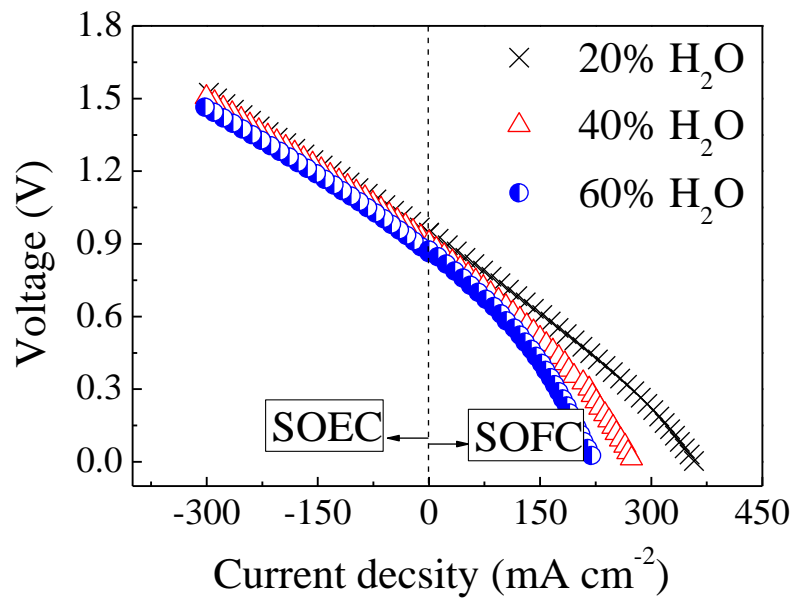

Fig. 7. $j$ - $V$ curves of the PSTF ||$S D C \mid Y S Z \| L S M-Y S Z$ single cell in different atmosphere at $800{ }^{\circ} \mathrm{C}$. 

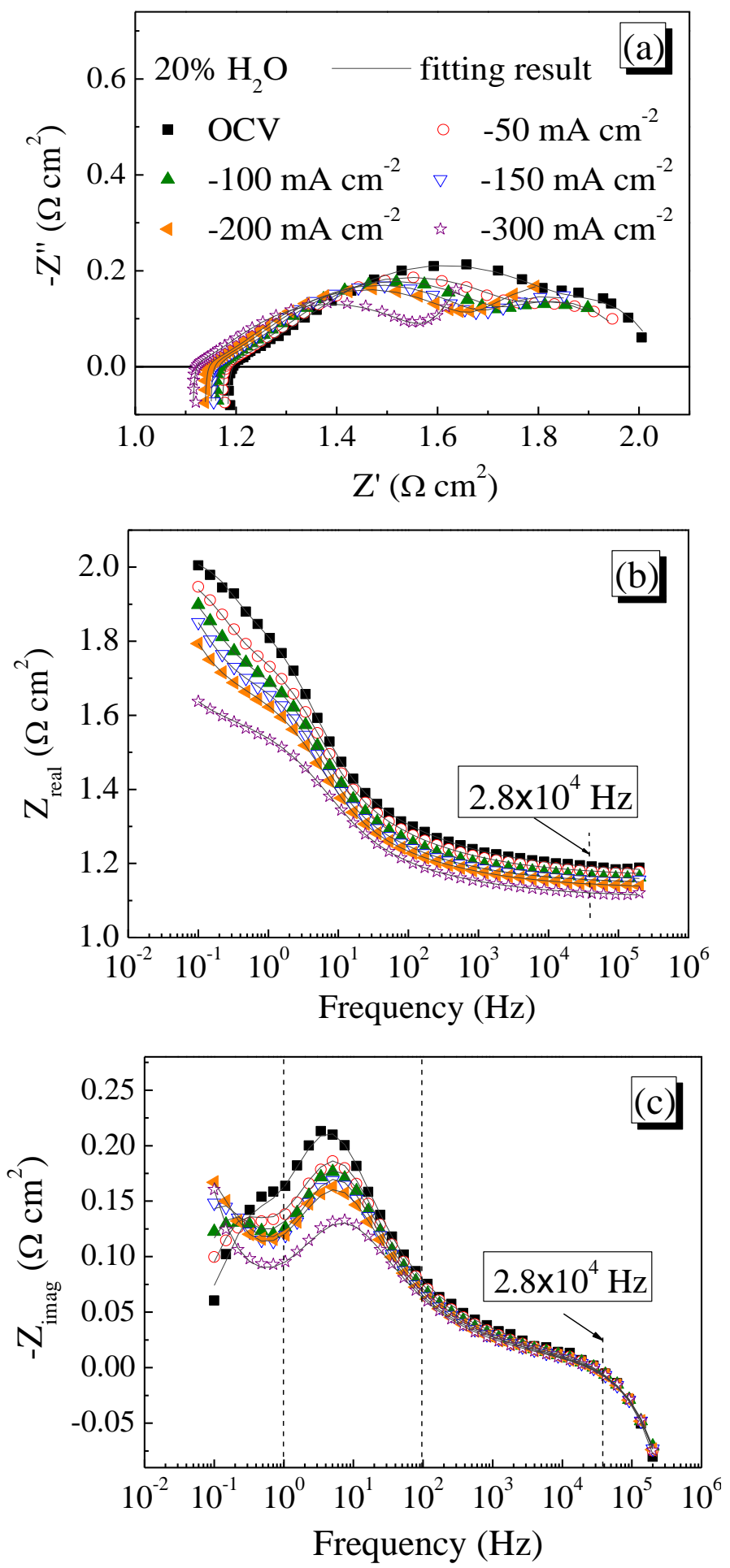

Fig. 8. Cell impedance spectra with different current density for $\mathrm{H}_{2} \mathrm{O}$ electrolysis in $\mathrm{Ar} / \mathrm{H}_{2} / 20 \% \mathrm{H}_{2} \mathrm{O}$ at $800{ }^{\circ} \mathrm{C}$. (a) Complex plane and (b and c) Bode presentations. 

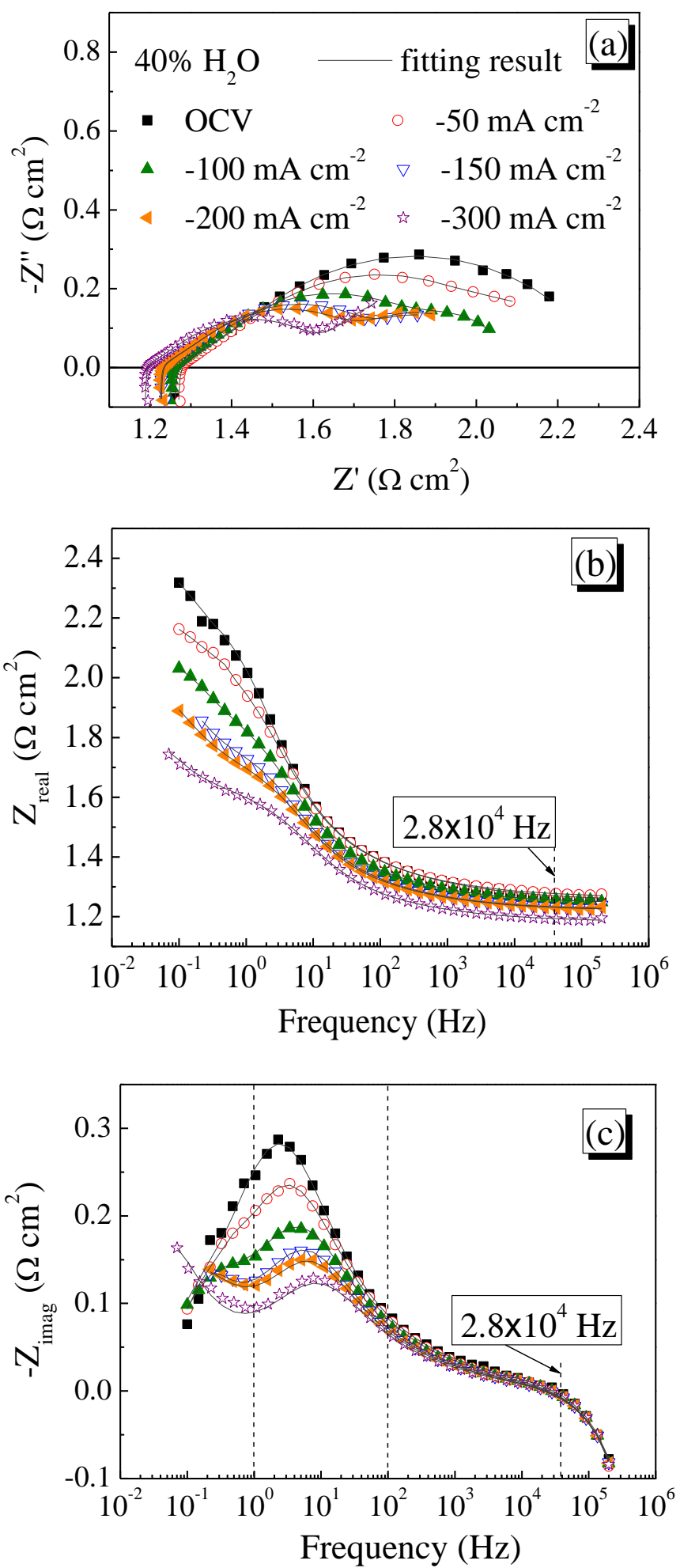

Fig. 9. Cell impedance spectra with different current density for $\mathrm{H}_{2} \mathrm{O}$ electrolysis in $\mathrm{Ar} / \mathrm{H}_{2} / 40 \% \mathrm{H}_{2} \mathrm{O}$ at $800{ }^{\circ} \mathrm{C}$. (a) Complex plane and (b and c) Bode presentations. 

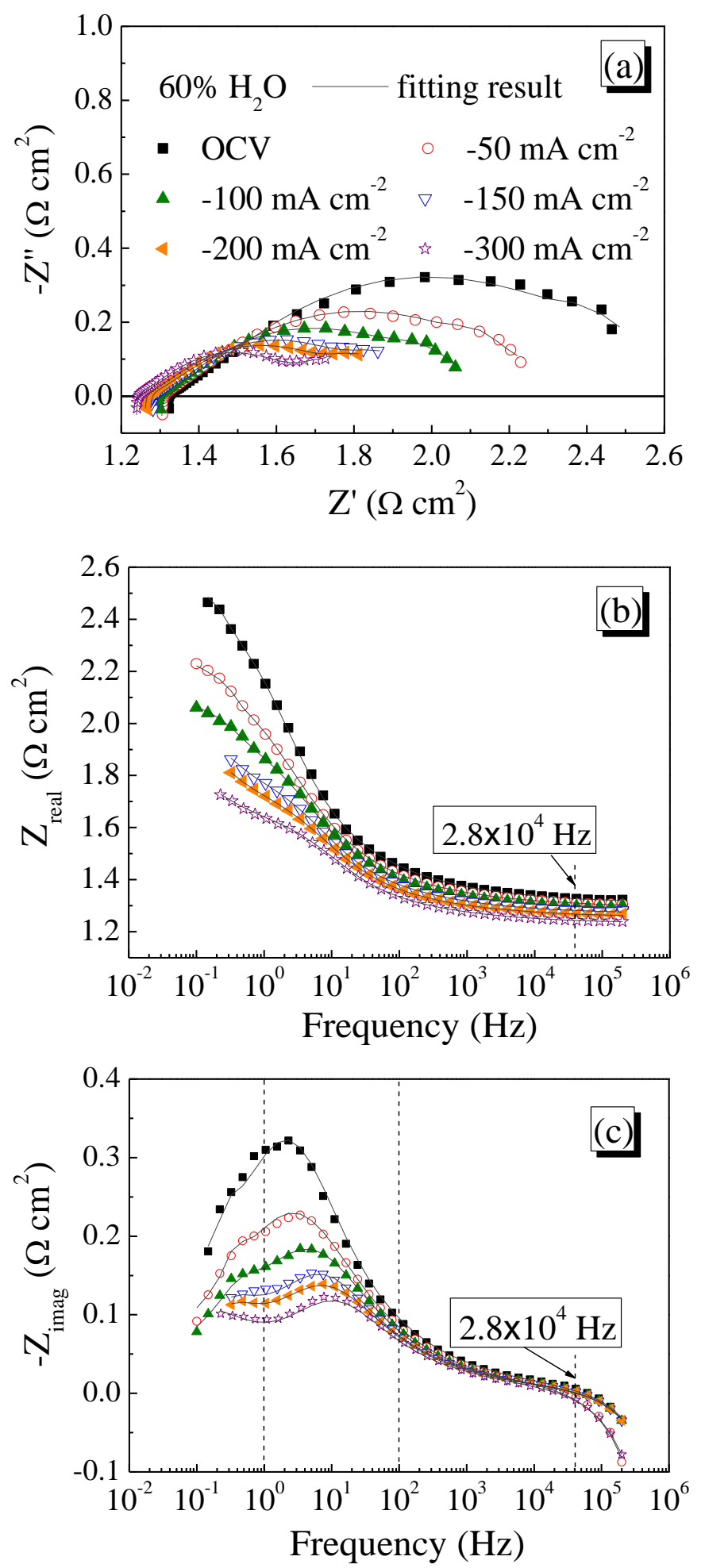

Fig. 10. Cell impedance spectra with different current density for $\mathrm{H}_{2} \mathrm{O}$ electrolysis in $\mathrm{Ar} / \mathrm{H}_{2} / 60 \% \mathrm{H}_{2} \mathrm{O}$ at $800{ }^{\circ} \mathrm{C}$. (a) Complex plane and (b and c) Bode presentations. 


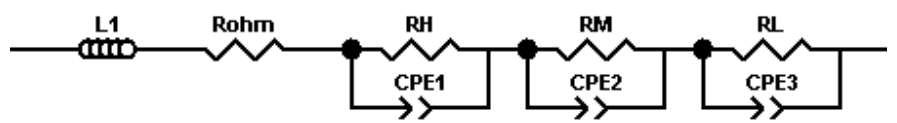

Fig. 11. The equivalent circuit for $\mathrm{AC}$ impedance spectra fitting of the PSTF $\mid$ SDC $\mid$ YSZ $\mid$ LSM-YSZ cell at $800{ }^{\circ} \mathrm{C}$. 


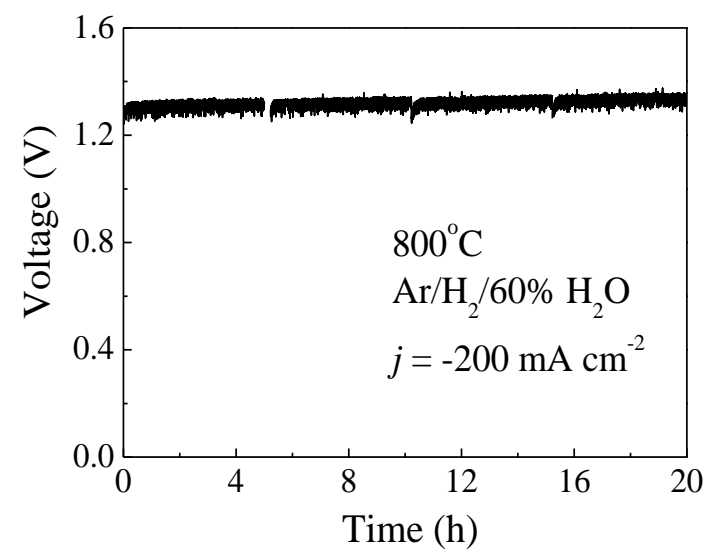

Fig. 12. The change of electrolyzer terminal voltage vs. time for PSTF electrode in $\mathrm{Ar} / \mathrm{H}_{2} / 60 \% \mathrm{H}_{2} \mathrm{O}$ at $800{ }^{\circ} \mathrm{C}$ when $j$ is $-200 \mathrm{~mA} \mathrm{~cm}{ }^{-2}$. 
Table 1 . Total conductivity of several common hydrogen electrode materials.

\begin{tabular}{cccc}
\hline Material & Atmosphere & $T\left({ }^{\circ} \mathrm{C}\right)$ & Conductivity $\left(\mathrm{S} \mathrm{cm}^{-1}\right)$ \\
PSTF & & 700 & 0.10 \\
& $5 \% \mathrm{H}_{2} / \mathrm{N}_{2}$ & 750 & 0.17 \\
& & 800 & 0.25 \\
$\mathrm{SrFe}_{0.75} \mathrm{Ti}_{0.25} \mathrm{O}_{3-\delta}$ & $5 \% \mathrm{H}_{2} / \mathrm{Ar}$ & 700 & $0.8[27]$ \\
$\mathrm{Sr}_{0.92} \mathrm{Y}_{0.08} \mathrm{Ti}_{0.7} \mathrm{Fe}_{0.3} \mathrm{O}_{3-\delta}$ & $\mathrm{H}_{2}$ & 800 & $0.56[28]$ \\
$\mathrm{La}_{0.5} \mathrm{Sr}_{0.5} \mathrm{Fe}_{0.5} \mathrm{Ti}_{0.5} \mathrm{O}_{3-\delta}$ & $5 \% \mathrm{H}_{2} / 95 \% \mathrm{~N}_{2}$ & 900 & $<0.10[12]$ \\
$\mathrm{La}_{0.75} \mathrm{Sr}_{0.25} \mathrm{Cr}_{0.5} \mathrm{Mn}_{0.5} \mathrm{O}_{3-\delta}$ & $5 \% \mathrm{H}_{2} / \mathrm{Ar}$ & 700 & $0.693[29]$ \\
$\mathrm{La}_{0.75} \mathrm{Sr}_{0.25} \mathrm{Cr}_{0.5} \mathrm{Mn}_{0.4} \mathrm{Sc}_{0.1} \mathrm{O}_{3-\delta}$ & & & $0.185[29]$ \\
\hline
\end{tabular}


Table 2. The electrochemical performance of several different electrolysis cells.

\begin{tabular}{|c|c|c|c|c|c|c|}
\hline Hydrogen Electrode & Cell structure & $\begin{array}{c}V \\
(\mathrm{~V})\end{array}$ & $\begin{array}{c}T \\
\left({ }^{\circ} \mathrm{C}\right)\end{array}$ & Feed gas & $\begin{array}{c}j \\
(\mathrm{~mA} \\
\left.\mathrm{cm}^{-2}\right)\end{array}$ & $\begin{array}{c}R_{p} \\
\left(\Omega \mathrm{cm}^{2}\right)\end{array}$ \\
\hline \multirow{3}{*}{$\mathrm{Pr}_{0.3} \mathrm{Sr}_{0.7} \mathrm{Ti}_{0.3} \mathrm{Fe}_{0.7} \mathrm{O}_{3-\delta}$} & \multirow{3}{*}{ 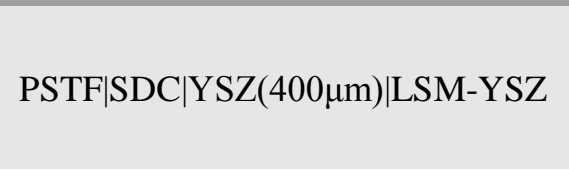 } & 1.50 & \multirow{3}{*}{800} & $\mathrm{Ar} / \mathrm{H}_{2} / 20 \% \mathrm{H}_{2} \mathrm{O}$ & 285 & $>1.75$ \\
\hline & & 1.50 & & $\mathrm{Ar} / \mathrm{H}_{2} / 40 \% \mathrm{H}_{2} \mathrm{O}$ & 298 & 0.99 \\
\hline & & 1.46 & & $\mathrm{Ar} / \mathrm{H}_{2} / 60 \% \mathrm{H}_{2} \mathrm{O}$ & 302 & 0.70 \\
\hline Ni-YSZ & Ni-YSZ|YSZ|LSM(HTCeramix) & 1.16 & 800 & 50 vol. $\% \mathrm{AH}$ & 560 & $0.45[33]$ \\
\hline $\mathrm{La}_{0.75} \mathrm{Sr}_{0.25} \mathrm{Cr}_{0.5} \mathrm{Mn}_{0.5} \mathrm{O}_{3-\delta}$ & 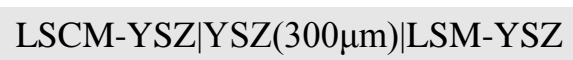 & 1.213 & 800 & 40 vol. $\% \mathrm{AH}$ & 120 & $0.9[8]$ \\
\hline $\mathrm{La}_{0.75} \mathrm{Sr}_{0.25} \mathrm{Cr}_{0.5} \mathrm{Mn}_{0.5} \mathrm{O}_{3-\delta}$ & LSCM-YSZ|YSZ $(15 \mu \mathrm{m}) \mid \mathrm{LSM}$ & 1.66 & 850 & 45 vol. $\% \mathrm{AH}$ & 330 & $0.7[34]$ \\
\hline$\left(\mathrm{La}_{0.3} \mathrm{Sr}_{0.7}\right)_{0.9} \mathrm{Ti}_{0.9} \mathrm{Ni}_{0.1} \mathrm{O}_{3-\delta}$ & LSTN-SDC|YSZ(2mm)|LSM-SDC & 1.6 & 800 & $3 \% \mathrm{H}_{2} \mathrm{O} / 5 \% \mathrm{H}_{2} / \mathrm{Ar}$ & 60 & $5.8[35]$ \\
\hline $\mathrm{La}_{0.3} \mathrm{Sr}_{0.7} \mathrm{TiO}_{3+\delta}$ & LSTO|YSZ(2mm)|LSM-YSZ & 1.5 & 900 & $47 \% \mathrm{H}_{2} \mathrm{O} / 3 \% \mathrm{H}_{2} / 50 \% \mathrm{Ar}$ & 85 & $1.4[36]$ \\
\hline
\end{tabular}

Note: part of the data is observed from the pictures in the references. 